been allowed to increase in value against other European currencies. Lawson made a clean breast of his dilemma last week: despite the $£ 14,000$ surplus, he had no room for manoeuvre.

Notoriously, exactly the same is true in the United States, where the Deficit Reduction Act (better known as Gramm-Rudman after two of its three sponsors) puts a statutory and reducing ceiling (to be fixed finally only in the summer) on the federal budget deficit. Again, the government has no room for manoeuvre. Part of the trouble is that more than a third of US spending is fixed by various acts of Congress, while just under a third goes on defence. Because savings in the United States are not great enough to bridge the gap, the deficit has been financed by borrowing from elsewhere (which is why there is a trade deficit). Over the past 18 months, two devices have been used to correct the balance - interest rates have been increased (as in Britain) but the value of the US dollar has been allowed to decline. This house of cards depends on people's willingness to continue turning foreign currencies into dollars to bridge the gap; ideally, the lenders would have been given proof of a deal between the administration and the Congress early in the new presidency, but even optimists are now talking of cutting a deal only in the summer. The sharp if modest fall of the stock markets last week, ostensibly from fears of still higher interest rates, may be a sign that the delicate apparatus has begun to crumble.

Mr Mikhail Gorbachev is similarly hemmed in. The Soviet Union's budget is believed to be 20 per cent in deficit, but the consequent inflation is only marginally apparent because most prices are centrally controlled. Because there is so little on which people can spend money, they save it against the time when the shops are full again. Last week, Gorbachev outlined an agricultural reform that would have seemed revolutionary before he came to office; farmers are to be allowed personally to lease the land they farm on the grounds that they will then become more efficient, but the details are not yet made public and are probably still to be decided. One snag, not nearly as well advertised, is that even more efficient farmers will not grow more food unless prices are also increased, perhaps even by a free-market mechanism. Sadly, even the bare bones of the scheme will give ideological offence.

Why should three substantial governments be thus hamstrung? To compare the United States and the Soviet Union economically is absurd, but that is not the end of it. The United States is locked into a straitjacket because, despite the astonishing flexibility of its economy and the steady growth of production, expectations have stolen a march on real wealth. President Bush's hope, like his predecessor's, is that the United States will grow out of trouble, but even the present modest rate of growth is judged dangerously fast. The safer short-term remedy is modestly to reduce consumption, which the new president has promised he will not, but in the long run only an increase of productivity (rather than of mere production) will square the circle. Exactly the same applies in the Soviet Union, but should be more achievable, given both the encouraging and the admonitory examples with which the world is littered. And, as it happens, the same longterm remedy is what Britain should also be looking for. The box in which Lawson is imprisoned would be less constraining if it were possible to spend (or give away) some or all of that budget surplus without rocking the boat. Maybe the three people chiefly concerned should put their heads together.

\section{Universities in arms}

British academics are faced with a nasty choice between a poor pay award and a continuing labour dispute.

THE reasons for believing that British academics are underpaid do not strain the imagination. Salaries have grown less quickly than those in other professional walks of life over the past decade of general deprivation for universities, and now compare so much less well than those in industry and elsewhere that university teachers and researchers are on the march to other jobs. The more serious worry is that recruitment to academic research at all levels is quickly drying up. Even school-leavers have learned that the academic profession is not much valued by the academic system's paymasters. Since the beginning of this year, academics have been declining to mark examination papers; now they have to choose between the continuation of that fruitless pursuit and their employers' offer of a salary increase of 6.5 per cent (which for practical purposes covers a two-year spell). The best course is to settle for what is on offer, but to prepare to fight a better battle next year.

The world, by now, knows that the vast majority of universities do not have the funds with which to pay more than they have offered. The whole world should also know that the British system cannot continue as in the past without running into serious difficulties. Hitherto, British academic pay has been determined nationally, by negotiation between the Association of University Teachers and the Committee of Vice-Chancellors and Principals. But the British university system is now well on the way to a welcome diversity in which some universities will be more able than others to pay good salaries. Disparities can only be further accentuated if the British government decides that the time has come to increase, perhaps double, the tuition fees paid from public funds to the universities which students attend, but recovering the cost from running budgets. Then universities will be competing tooth and nail for students.

Whether academics (or their union) welcome this development, it is happening and will continue. Nationally negotiated pay awards are bound eventually to disappear. It would be sensible to anticipate that certainty, if only for the sake of the greater say that academics would thereby acquire in the management of their own institutions. 